\title{
Production of Fuel Briquettes from Bamboo and Agricultural Residue as an Alternative to Charcoal
}

\author{
Patrick Mulindwa ${ }^{1,2^{*}}$, Dan Egesa ${ }^{1}$, Anthony Osinde ${ }^{2}$, Esther Nyanzi ${ }^{3}$ \\ ${ }^{1}$ Division of Industrial Chemistry, Department of Chemistry, School Physical Sciences, College of Natural Sciences, Makerere \\ University, Kampala, Uganda \\ ${ }^{2}$ Energy Research and Development Center, Faculty of Engineering, Ndejje University, Kampala, Uganda \\ ${ }^{3}$ Uganda National Renewable Energy and Energy Efficiency Alliance (UNREEEA), Kampala, Uganda \\ Email: *patrickmulindwa@gmail.com
}

How to cite this paper: Mulindwa, P., Egesa, D., Osinde, A. and Nyanzi, E. (2021) Production of Fuel Briquettes from Bamboo and Agricultural Residue as an Alternative to Charcoal. Journal of Sustainable Bioenergy Systems, 11, 105-117. https://doi.org/10.4236/jsbs.2021.113008

Received: June 30, 2021

Accepted: August 8, 2021

Published: August 11, 2021

Copyright (c) 2021 by author(s) and Scientific Research Publishing Inc. This work is licensed under the Creative Commons Attribution International License (CC BY 4.0).

http://creativecommons.org/licenses/by/4.0/

\begin{abstract}
The study was done to explore the potential of producing fuel briquettes that could meet the need for energy in Uganda, especially Kampala city. The primary objective of this work was to produce fuel briquettes from homogeneous and heterogeneous combinations of carbonized maize cobs, Bamboo poles and charcoal dust. For the primary objective to be achieved, the main activities which were performed included; chopping bamboo poles, sorting maize cobs, carbonization, crushing, binder preparation, mixing, extrusion, drying and quality assessment of the fuel briquettes. The maize cobs and charcoal dust used for this work were purchased from the farmers and charcoal sellers respectively from the districts of Luwero and Nakaseke. Bamboo poles were provided by Divine bamboo group. The homogenous combinations included $100 \%$ maize cob char, $100 \%$ bamboo char and $100 \%$ charcoal dust. Heterogeneous combinations included $75 \%$ bamboo char $+25 \%$ charcoal dust and $25 \%$ bamboo char $+75 \%$ charcoal dust. The test results for both homogenous and heterogeneous combinations of fuel briquettes had ranges of moisture content $8 \%-11 \%$, Volatile matter $12 \%$ - 23\%, Ash content 33\% - 39\%, Heating Value 16 - $22 \mathrm{MJ} / \mathrm{Kg}$, Fixed Carbon 30\% - 51\% and moisture content $8 \%$ 9\%, Volatile matter 13\% - 19\%, Ash content 27\% - 44\%, Heating Value 16 $18 \mathrm{MJ} / \mathrm{Kg}$, Fixed Carbon 30\% - 51\% respectively. The test results for drop resistance, density and Compressibility strength for both homogeneous and heterogeneous combinations had ranges of $7 \%-56 \%, 214-941 \mathrm{~kg} / \mathrm{m}^{3}, 0.077$ $0.544 \mathrm{~N} / \mathrm{mm}^{2}$ and $12 \%-28 \%, 869.1-958.3 \mathrm{~kg} / \mathrm{m}^{3}, 0.124-0.295 \mathrm{~N} / \mathrm{mm}^{2}$ respectively. These results were within the ranges reported in the literature especially for the heterogeneous combinations. Therefore, there is the possibili-
\end{abstract}


ty to use bamboo woody feedstock in combination with other agricultural waste feedstock for the production of fuel briquettes. We can increase the quality and production of fuel briquettes by using alternative feedstock sources rather than degrading the environment through deforestation.

\section{Keywords}

Bioenergy, Solid Biofuels, Briquette Quality

\section{Introduction}

The cooking energy mix in Uganda is dominated by unprocessed biomass (as firewood), with charcoal the next most utilized fuel. In Uganda, 95\% of all Ugandan households rely on charcoal, wood, or other forms of biomass for their household cooking needs [1]. According to the Global Alliance for Clean Cook stoves [2], unprocessed biomass makes up the majority of cooking fuels in Uganda.

Recent reports [2] [3] have indicated that the majority of rural households use firewood for cooking whilst in urban areas households use both firewood and charcoal. The prices of fuel especially in urban centers continue to rise and are subject to seasonal fluctuations as firewood becomes increasingly unavailable. This is further exacerbated by the decreasing land area covered by forest that is estimated from $15 \%$ to $26 \%$ of Uganda's land area [2].

Biomass has historically been a cheap and accessible source of fuel for Uganda's population but this is unlikely to continue as a high dependency is raising concerns for the sustainability of the resources as human populations and competing demands increase [4]. Furthermore, the unsustainable depletion of woody biomass reserves portends several negative consequences for the country's population, including increased energy insecurity, unaffordable rise in wood fuel prices, climate change from deforestation and increased rural-urban migration. The conversion of forests to other land uses contributes $38 \%$ of Uganda's national GHG emissions [5]. Degeneration of biomass is further exacerbated by the lack of effective interpectoral and institutional coordination, deteriorating feedstock sources, market development challenges and difficulties in changing mindsets and behavior towards the transition to modern forms of energy [6].

The Bamboo plant is now famous for being one of the top solutions to quick economic growth and mitigation of climate change due to its numerous unique characteristics. Uganda has embraced this plant with several small-scale mushrooming bamboos-based businesses [7]. Furthermore, bamboo plants are the fastestgrowing plant species on Earth (approximately $91-122 \mathrm{~cm}$ per day) and have been reported to be widely spread in tropical and subtropical climate regions [8] [9] [10].

Unfortunately, much as several developmental projects on energy are coming up and thriving in other countries using bamboo, Uganda has not yet explored this option. Therefore, the aim of this study was to evaluate the potential of bam- 
boo for briquette fuel production.

\section{Materials and Methods}

\subsection{Collection and Sorting and Weighing of the Materials}

The maize cobs used for this work were purchased from the farmers from districts of Luwero and Nakaseke. Bamboo poles were provided by Divine bamboo group. Maize cobs and bamboo poles were sorted and chopped to a reduced size respectively, in order to fit in the carbonizer. A known weight of both maize cob and bamboo chopped materials were loaded into the carbonizer at different times for carbonization.

\subsection{Carbonization of the Materials}

Carbonization of the materials was done using a fixed kiln purely made of masonry material such as bricks, cement, sand and some metal pieces of high heat resistance. The exhaust gases leaving the carbonizer were less harmful to the environment due to the auto thermal treatment inside the chimney during biomass material carbonization. The carbonizer has a capacity of 1 ton and efficiency of $25 \%$ for agro waste such as maize cobs (Figure 1).

\subsection{Crushing System}

The crusher used was fabricated with a feeding back, grinding hammer and outlet where the crushed char dust is collected from. Its powered by $7.5 \mathrm{Hp}$ electric motor running on 3 phase with a capacity of at least 1 ton per day.

\subsection{Preparation of the Binders}

For this study, molasses was used as the binding material for all the briquette samples. The mixing proportions of the binder were based on the mixing ratios of each sample.

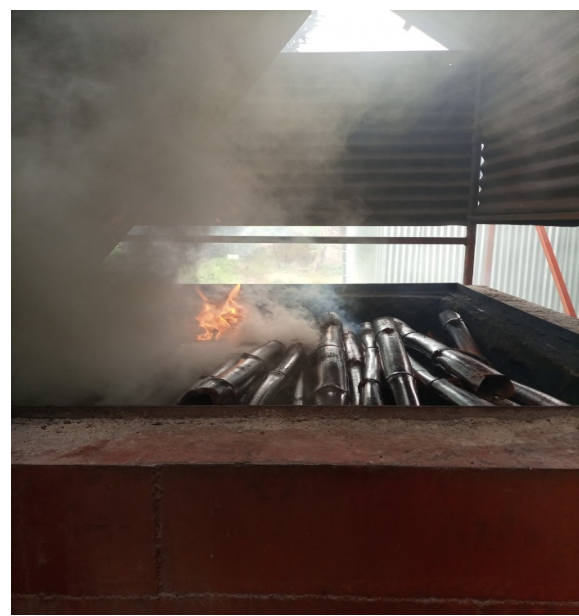

(a)

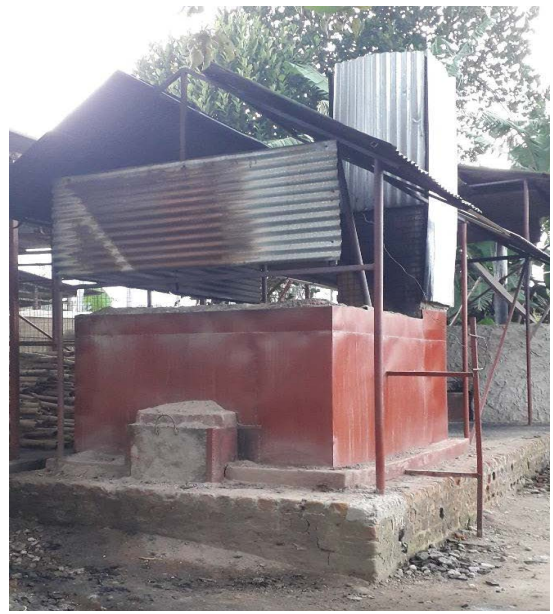

(b)

Figure 1. (a) Bamboo carbonization; (b) Carbonizer left to cool. 


\subsection{Material Mixing Process}

During the production process, the material was mixed on the floor using a hoe and a sped as shown in Figure 2 below.

\subsection{Briquettes Extrusion}

The extruder which was used was built with different parts such as the feeding bucket, convey channel, extrusion screw and an outlet. The extruder machine is powered by electrical powered motor of 3 phases, $7.5 \mathrm{Hp}$. The extruder had an output capacity of at least 1 ton per day.

\subsection{Briquette Drying Process}

Drying of the sample briquettes was done under the structure covered with UV foil to enable high concentration of heat with in the structure.

\subsection{Analysis of Physical and Chemical Parameters}

The apparatus used was the computerized Thermographic Analyzer with an in built and integrated ELTRA $84 \mathrm{GmbH}$ Precision Digital weighing scale. The analyser is integrated with a non-oxidizing (99.99\% pure argon gas or $99.999 \%$ pure Nitrogen gas) environment and an oxidizing (99.99\% Pure oxygen) environment which are computer controlled by Tga Software version: Tga 1.4.2.12 with internally programmed application for analyzing physical properties of biomass in four stages namely moisture content, volatile matter, fixed carbon and ash content. Specimens were extracted from each of the samples submitted. They were homogenized by crushing into a powder. The 3 specimens of minimum weight 1100 milligrams are placed in three of the 19 work stations of the Thermographic Analyser. An inbuilt program of the Tga software version 1.4.2.12 for analyzing biomass is triggered to commence the analysis which lasts a minimum of 6 hours. The moisture content, volatile matter and fixed carbon are analyzed in a purely non oxidizing environment and ash content is analyzed in a pure oxidizing environment.

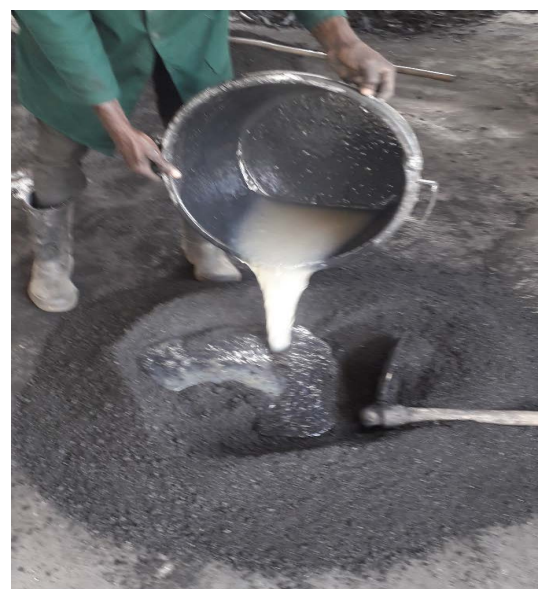

Figure 2. Material mixing. 


\subsection{Heating Value}

The apparatus used included An IKA C2000 Automated Digital bomb calorimeter and a Precision Denver S1-234 Digital Weighing scale ( $\pm 0.0001 \mathrm{~g}) .3$ specimens were extracted from each of the sample you submitted and weighed on a Precision Denver S1-234 Digital Weighing scale $( \pm 0.0001 \mathrm{~g})$ and its mass recorded. The specimens were then put a crucible and enclosed a bomb carrying out the heating value tests independently. The higher heating value of the samples was measured using an internal programme in the IKA C2000 Digital bomb calorimeter. Samples weighing between $700 \mathrm{mg}$ to $1500 \mathrm{mg}$ are placed in the bomb calorimeter and subject them to complete combustion in an adiabatic environment which is internally stabilized by a computer, heaters and circulating water. The Higher Heating Value (HHV) was calculated from measured temperature increase in the adiabatic system by a software and results are given.

\subsection{Bulky Density Tests}

The apparatus used were ELTRA 84 Digital weighing scale and Vanier caliper. Three specimens were extracted from each of the sample. The specimen's dimensions were measured and weight taken at room temperature using the digital weighing scale and the results were tabulated. The formula below was used for determining the bulky density.

$$
\rho=\frac{m}{v}
$$

where: $v=v_{1}-v_{2}$

$V_{1}$ : Volume based on the external diameter;

$v_{2}$ : Volume based on the internal diameter.

\subsection{Compression Tests}

Three specimens were extracted from each of the sample by cutting using a hack saw blade and were tested on a Computerized Testometric Universal Testing Machine made in UK and results were tabulated.

\subsection{Drop Resistance Tests}

Each of the two samples was pre weighed, recorded the mass weight as $M_{1}$. At a height of $150 \mathrm{~cm}$, the samples were dropped three times, solid particles weighed and recorded as $M_{2}$. To get the percentage possibility of breakage, $M_{2}$ was subtracted from $M_{1}$, divided by $M_{1}$, multiplied by $100 \%$.

$$
\frac{M_{1}-M_{2}}{M_{1}} \times 100 \%
$$

\section{Results and Discussion}

\subsection{Chemical Properties (Moisture Content (MC), Volatile Matter (VM), Ash Content (AA), Heating Value (HV) and Fixed Carbon (FC))}

The present section describes the chemical parameters of the investigated mate- 
rials, the required levels of which must be respected in practice, otherwise their burning (in the form of bio-briquette fuel) could cause environmental pollution.

Heating value/calorific value is the most important indicator of fuel chemical quality, which indicates the amount of energy released from fuel during burning [11]. The heating values for all feedstock ratios ranged from $16.027 \mathrm{MJ} \cdot \mathrm{kg}^{-1}$ to 21.26 MJ. $\mathrm{kg}^{-1}$ (Figure 3). Therefore, the tested materials exhibited a high level of such an indicator; thus, these results were satisfactory. However, results for briquette sample with $100 \% \mathrm{BC}$ and sample mixture of $75 \% \mathrm{BC} / 25 \% \mathrm{CD}$ were very good, thus proving the significant potential of bamboo for fuel briquette production as reported by other researchers [8] [12] [13].

As observed in Figure 4, it is clear that moisture content Mc (\%) during experimental measurements occurred at a suitable level for bio-briquette production (i.e., Mc < 15\%) [8] [14]. All the samples had moisture content values within the range reported in literature [8]. It's important to note that if moisture content exceeds the suitable level, it complicates the densification process or makes it completely impossible to realize it.

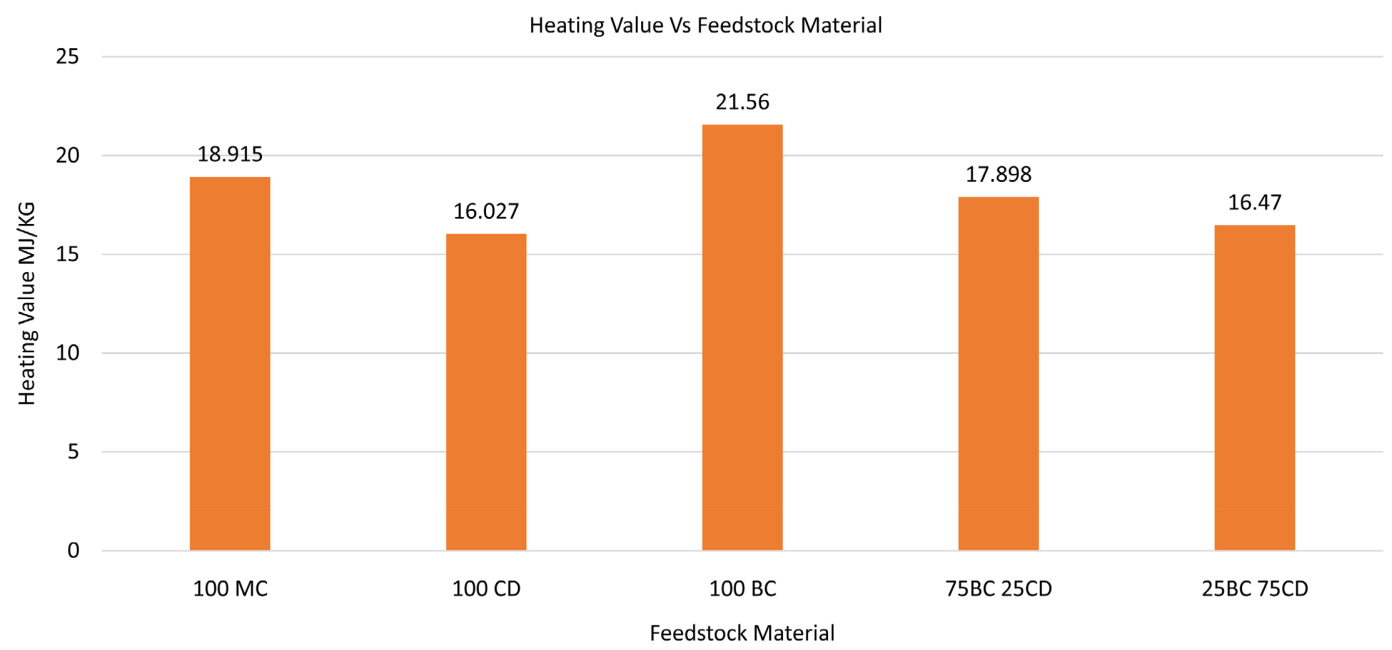

Figure 3. Heating value vs feedstock.

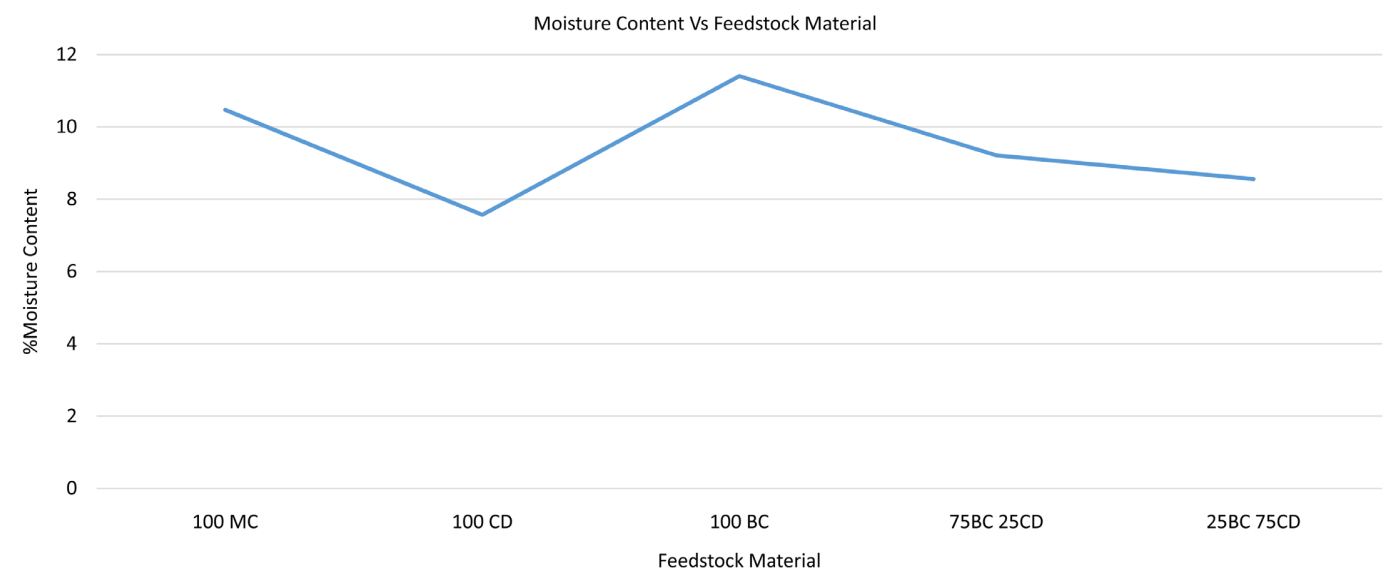

Figure 4. Moisture content vs feedstock material. 
The range of values for volatile matter $(11.97 \%$ and $23.2 \%)$ of briquettes produced in this study (Figure 5) is lower than range of $24.2 \%$ to $34.95 \%$ obtained by falemara et al. [15] for briquettes produced from agricultural wastes and wood residues, $43 \%$ to $49 \%$ obtained by Adegoke et al. [16] for briquettes produced from mixed sawdust of tropical hardwood species, $72.33 \%$ to $77.44 \%$ for briquettes produced from three hardwood species Emerhi et al. [17], and 68\% stated by Ige et al. [18]. However, results for briquette sample with $100 \%$ BC (11.97\%) and sample mixture of $75 \% \mathrm{BC} / 25 \% \mathrm{CD}(13.3 \%)$ were very good, thus proving the significant potential of bamboo material for fuel briquette production.

Volatile matter is a mixture of short- and long-chain hydrocarbons such as combustible or incombustible gases or combination of both released during burning. These gases strongly affect the combustion behavior of briquettes [15] [19]. Lower volatile matter is an indication that the briquettes might not be easy to ignite, but once ignited they will burn smoothly, while high volatile matter results in high combustibility at low ash content [15]. As such, blending of higher volatile material (wood residues) with lower volatile material (agro wastes) resulted in the production of optimum quality briquette. In contrast, the higher the volatile matter of a briquettes, the higher the amount of emissions during burning. This implies that low volatile matter is required for good quality briquette which agrees with the results of the present study.

As observed in (Figure 6), high ash content values were observed in the present study and it ranged from $26.8 \%$ to $44 \%$. The results of the present study matches those that were reported by Ige, et al. [18], Ikelle and Anyigor [20], Ogbuagu, et al. [21] and Emerhi [17] which ranged from $18 \%, 18.67 \%$ to $22.06 \%, 10.44 \%$ to $43 \%$ and $19.07 \%$ to $21.72 \%$ respectively. The high ash content could be a reflection of contamination of material due to external impurities (dust, soil) as reported by Brunerová, et al. [8]. Higher ash content in a fuel usually leads to higher dust emissions, air pollution, and affects the combustion volume and efficiency of combustion.

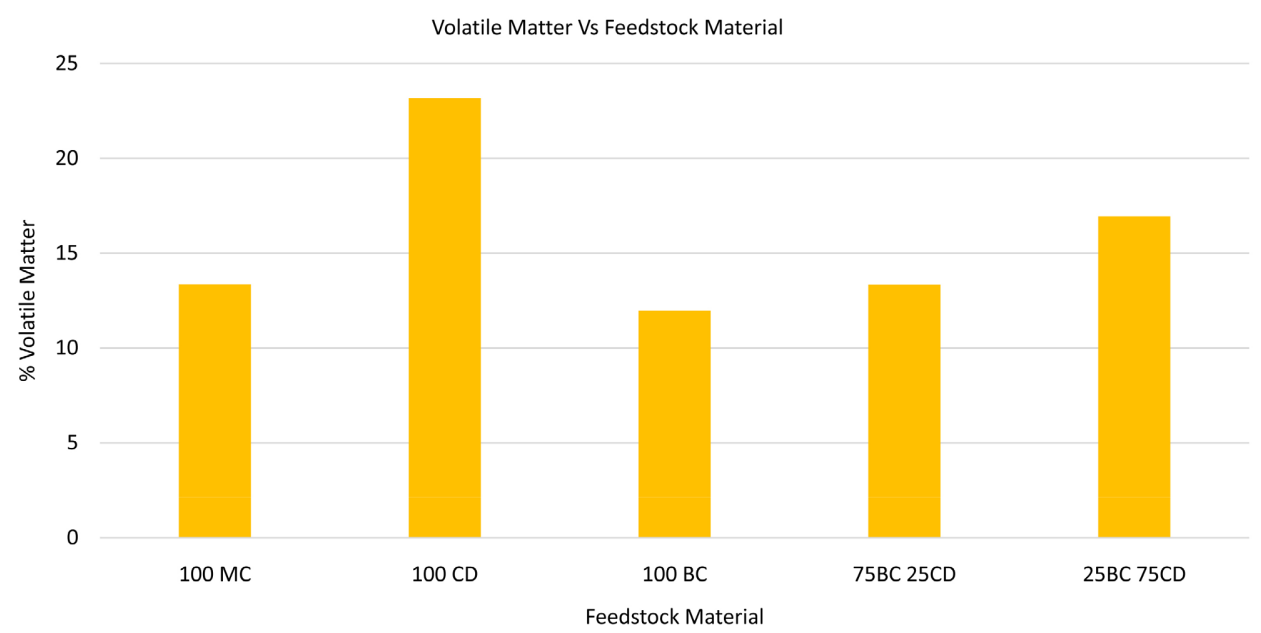

Figure 5. Volatile matter vs feedstock material. 


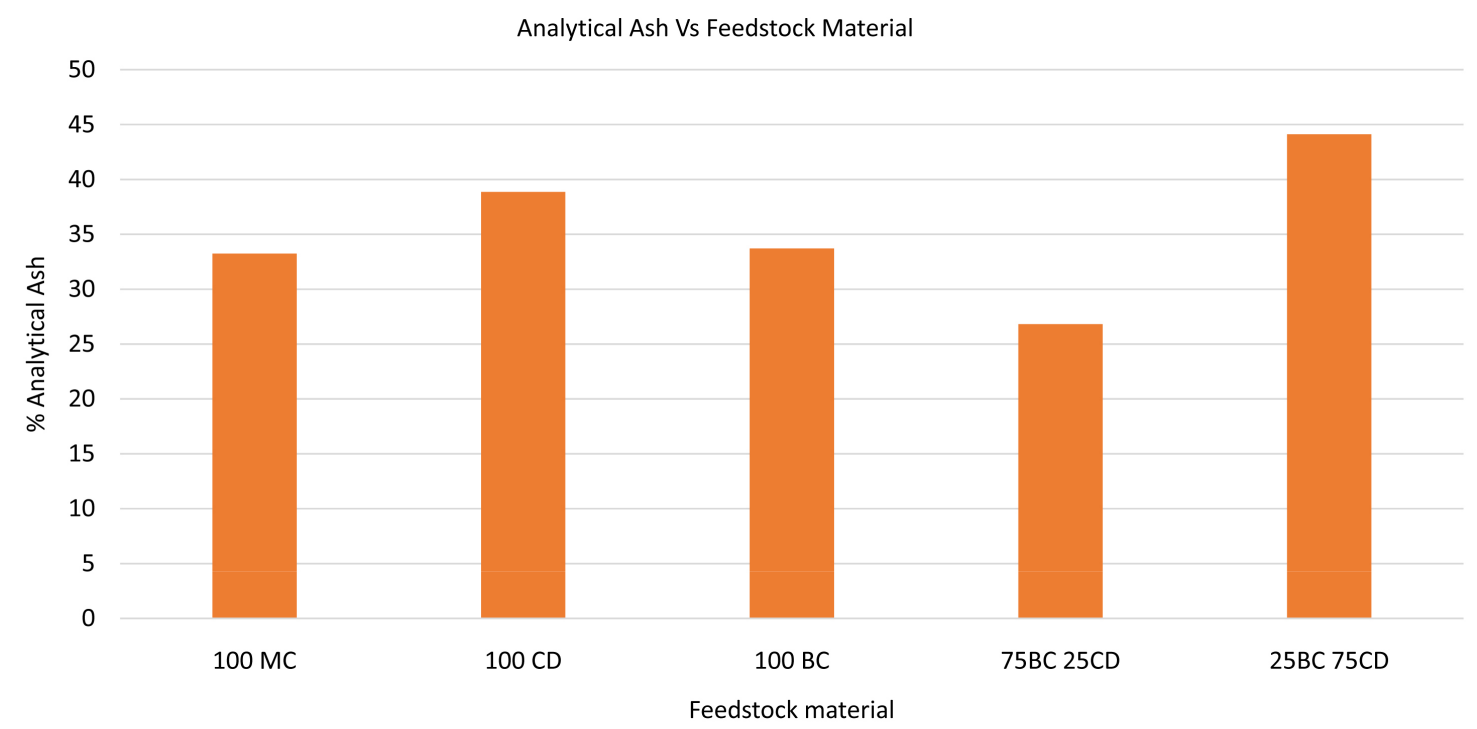

Figure 6. Analytical ash vs feedstock material.

Fixed carbon gives an indication of the proportion of char that remains after volatile matter is distilled off. It gives a rough estimate of the heating value of a fuel and acts as the main heat generator during burning [15] [22]. The fixed carbon content of briquettes produced ranged from $30.4 \%$ to $50.6 \%$ for all the samples. However, the fixed carbon as reported in this study is relatively higher than $9.06 \%$ to $11.46 \%$ obtained by Adegoke, et al. [16], 5.75\% to $8.28 \%$ stated by Emerhi [17], 16.80\% - 20.90\% quantified by Adetogun, et al. [23] and 15\% fixed carbon estimated by Ige, et al. [18] who all worked on briquettes produced from homogenous particles. A good quality and efficient fuel briquette is dependent on lower volatile matter and ash content with a higher fixed carbon content which agrees with results of the present study [24] (Figure 7).

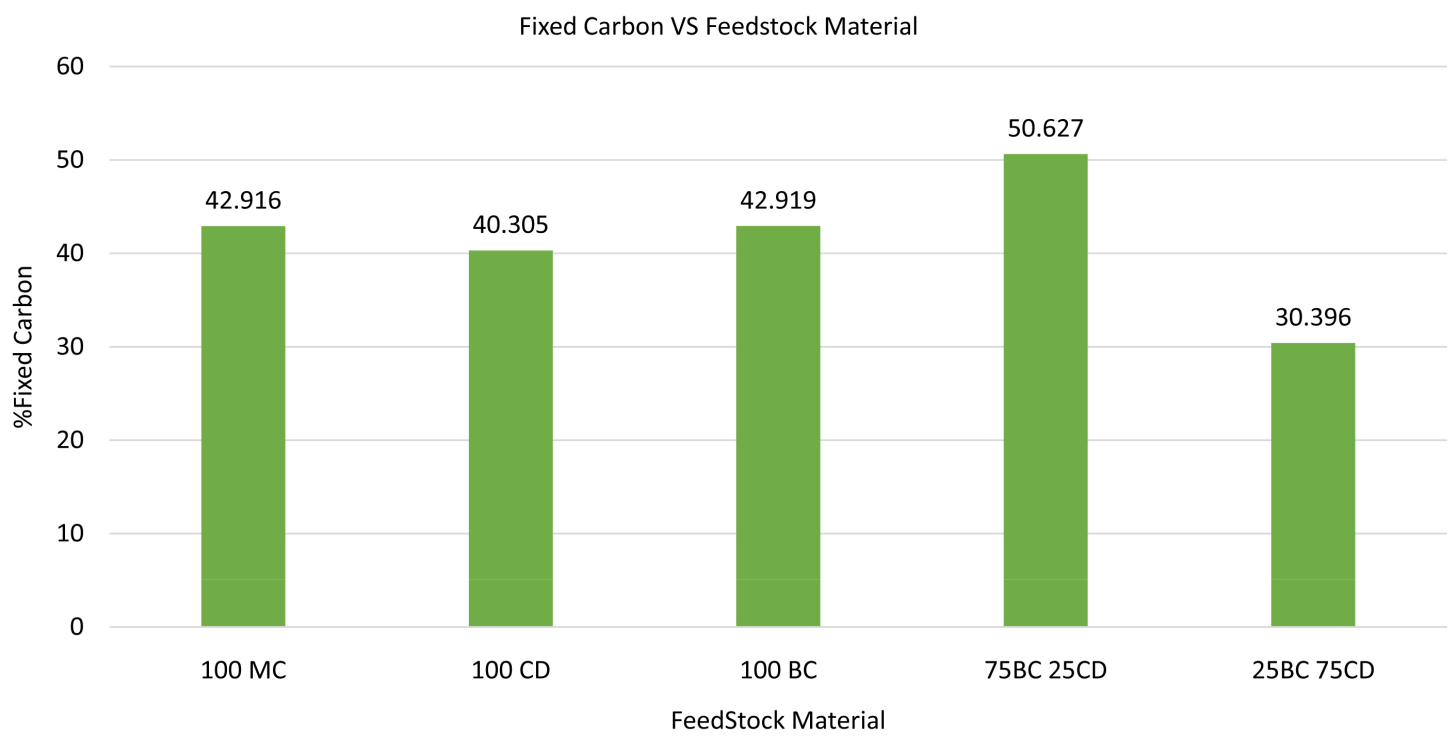

Figure 7. Fixed carbon vs feedstock material. 


\subsection{Physical Properties (Drop Resistance (DR), Compressibility Strength (CS) and Bulky Density (BD))}

The present section describes the physical/mechanical parameters of the investigated materials, the required levels of which must be respected in practice.

Drop resistance refers to the ability of briquettes to withstand drops and collisions during transportation and storage [25] [26]. By referencing to UNBS US 765-2: 2019 (Uganda National Bureau of Standards National Standard), where the required drop resistance to meet the good quality of briquette ranges from $2.5 \%$ to $10 \%$, the results from the present study, were slightly higher than the standard except for sample with $100 \%$ BC with a value of $7 \%$. Kaliyan and Morey [27] reported a lower drop resistance value of $0.50 \%-0.97 \%$ for corn Stover briquettes. The variance from the required standard can be attributed to the lower particle size due to mechanical interlocking of relatively short fibers [28] (Figure 8).

The ability of briquettes to withstand destructive forces during handling, storage, and transportation can be evaluated by compressive strength. The compressive strength of the briquettes indicates the amount of force required to break the briquette structure [25]. As shown in Figure 9, the compressibility strength

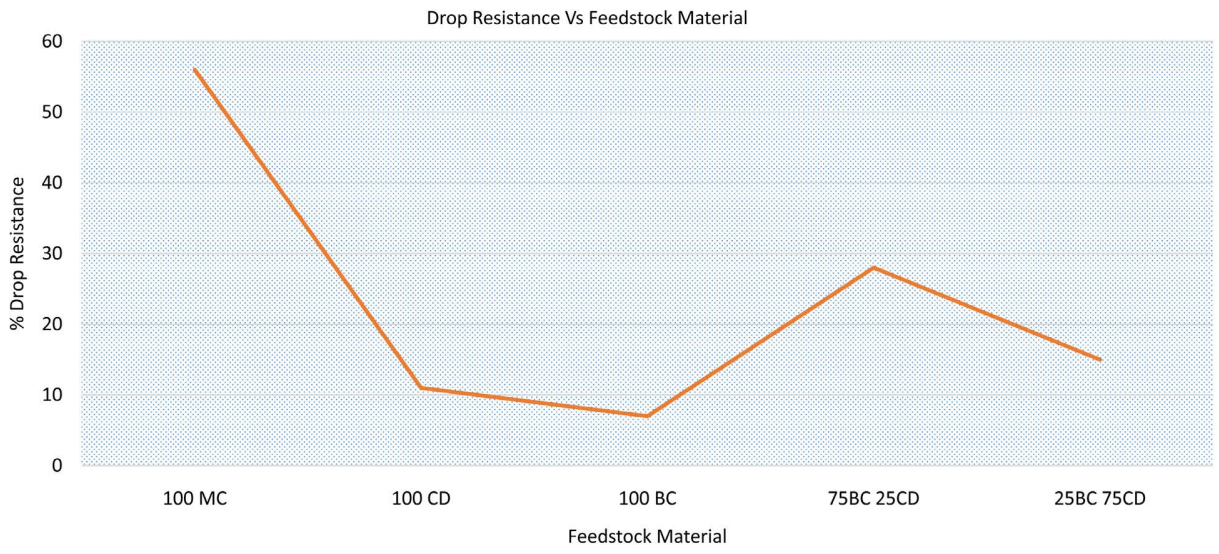

Figure 8. Drop resistance vs feedstock material.

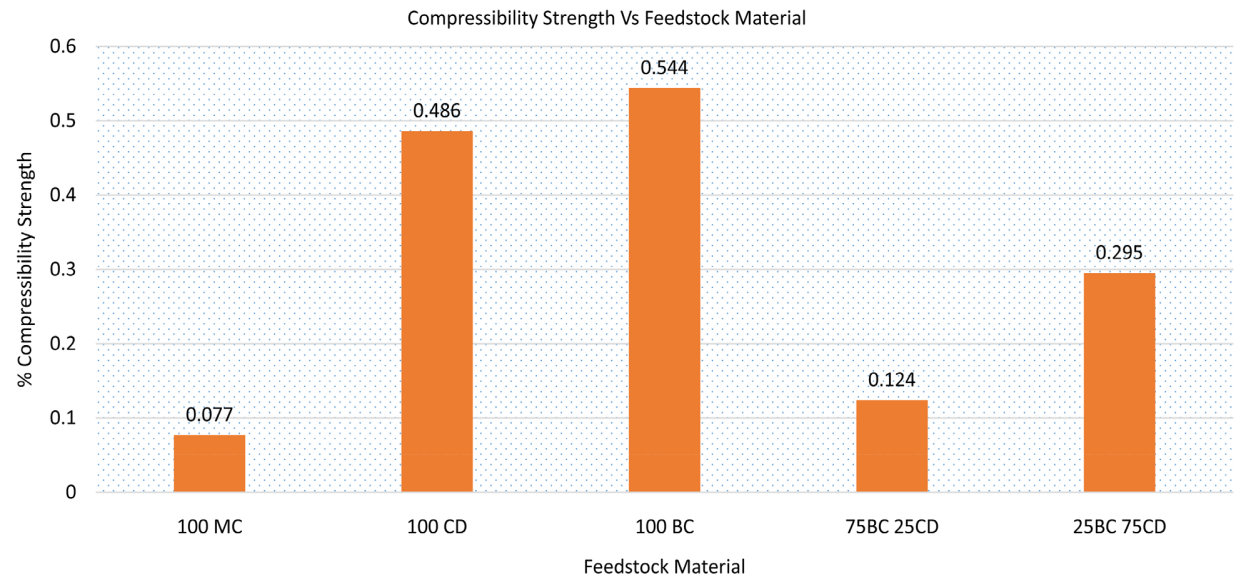

Figure 9. Compressibility strength vs feedstock material. 
for all the samples was lower than that reported by other researchers. The deviation in the results might have come about because of the mixing ratios and process temperatures. The effect of mixing ratios and process temperatures on the compressive strength of briquettes has been reported in recent publications [26] [29].

Observed bulky density $\rho$ data proved satisfactory results for all cases except sample with $100 \%$ BC. A bulk density of $869.1 \mathrm{~kg} / \mathrm{m}^{3}$ was observed for the heterogeneous mixture of $75 \% \mathrm{BC}$ and $25 \% \mathrm{CD}$, which indicates high quality bio-briquette fuel. As reported previously, bio-briquette fuel mechanical quality increases with increasing bulk density $\rho$ [8] [11] [30] because it indicates bio-briquette fuels' longer burning time and larger amount of produced heat [31]. According to other published research, the level of bulk density $\rho$ of high quality bio-briquette fuels should occur at approximately $1000 \mathrm{~kg} \cdot \mathrm{m}^{-3}$ [27] [32] [33] (Figure 10).

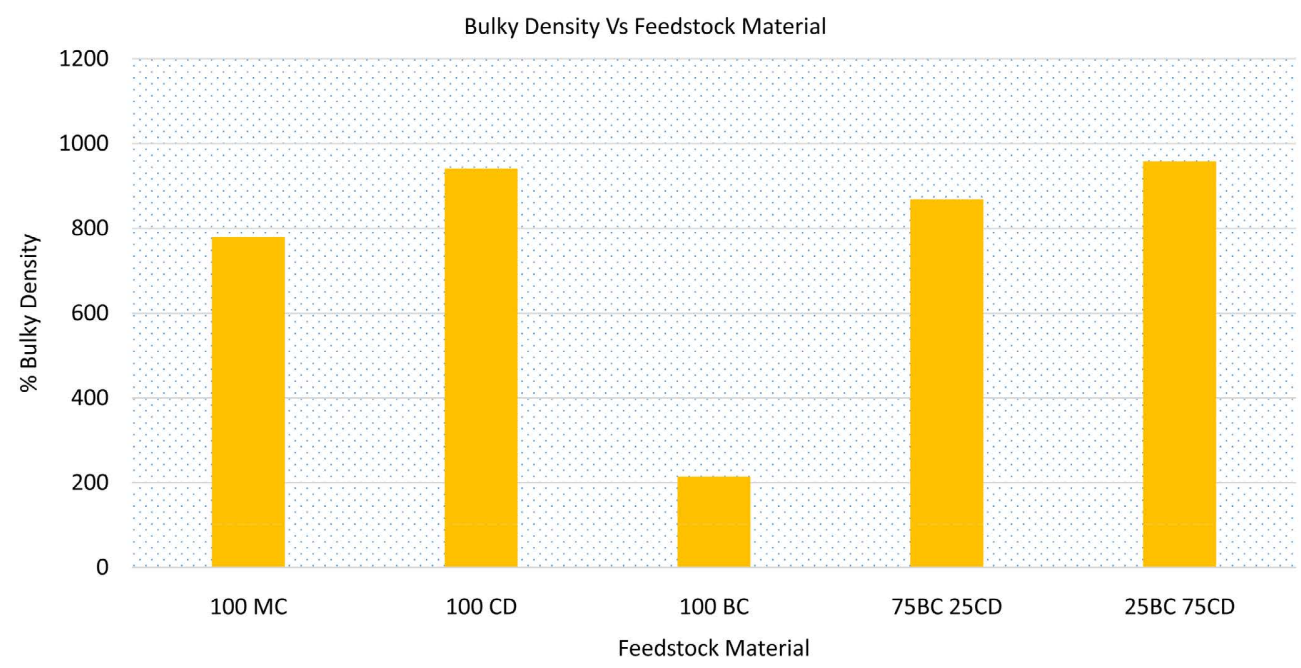

Figure 10. Bulky density vs feedstock material.

\section{Conclusions}

The study examined the physical and chemical properties of briquettes produced from wood residues (Bamboo and Charcoal dust) and agricultural wastes (corn cobs) as well as heterogeneous combination of the particles. The study affirmed that briquettes produced from $100 \% \mathrm{MC}, 100 \% \mathrm{BC}$ and a mixture of $75 \% \mathrm{BC}$ and $25 \% \mathrm{CD}$, had better quality in terms of density, agglomeration, compaction, and combustion properties with respect to high volatile matter, low ash content, high fixed carbon, and high heating value. There were little variations in the quality of the briquette produced from these three particle types compared to other heterogeneous particle types. This study has been able to confirm that agricultural wastes alongside wood waste can be utilized in producing quality briquettes. As such, wood wastes from Bamboo and a combination of Bamboo and charcoal dust particle type using molasses as a binder are suitable for briquette production due to better combustion performance. Furthermore, utilization of bamboo plant will provide alternative biomass feedstock sources for briquette production and help 
in the restoration of already destroyed forests in Uganda.

More studies to establish the combustion properties of more heterogeneous particle types that promote the utilization of wood and agro-wastes such as bamboo and Maize cobs are highly recommended. In order to reduce deforestation, the use of charcoal dust for briquette production should completely be discouraged.

\section{Acknowledgements and Funding}

This research was funded by Divine Bamboo Group Limited with support from Ndejje University Consults Ltd and the Energy Research and Development Center of Ndejje University. Particular thanks are offered to Divine Nabaweesi, Dr. Kakembo Fredrick, Jackson Ouma, Irene Kemigisha, and Musingi Cajo Francis, all of who have offered key insights into the findings of the study. Finally, a special thank to my family, especially my wife Sharon for your patience and involvement.

\section{Conflicts of Interest}

The authors declare no conflict of interest.

\section{References}

[1] Uganda Bureau of Statistics (UBOS) (2018) Uganda National Household Survey 2016/17. UBOS, Kampala.

[2] GACC, Global Alliance for Clean Cookstoves (2017) Comparative Analysis of Fuels for Cooking: Life Cycle Environmental Impacts and Economic and Social Considerations. http://cleancookstoves.org/assets-facit/Comparative-Analysis-for-Fuels-FullReport.pdf

[3] GVEP International (2012) Uganda Market Assessment Report. http://cleancookstoves.org/resources/178.html

[4] GVEP International Report (2012) Briquette Businesses in Uganda the Potential for Briquette Enterprises to Address the Sustainability of the Ugandan Biomass Fuel Market.

[5] FAO (2016) Wood Energy Catalogue, National Charcoal Survey for Uganda 2015, Final Report.

[6] Ministry of Energy and Mineral Development (MEMD) (2019) Priorities and Issues Paper.

[7] Nantongo, I. (2017) Techno-Economic Feasibility of a Gasification Plant for Rural Electrification, under a Bamboo Based Sustainable Economic Model: Case of Bududa District in Eastern Uganda, 2016-2017.

[8] Brunerová, A., Roubík, H. and Brožek, M. (2018) Bamboo Fiber and Sugarcane Skin as a Bio-Briquette Fuel. Energies, 11, 2186. https://doi.org/10.3390/en11092186

[9] Akinlabi, E.T., Anane-Fenin, K. and Akwada, D.R. (2017) Bamboo: The Multipurpose Plant. Springer International Publishing, Cham, Switzerland, 1-37. https://doi.org/10.1007/978-3-319-56808-9

[10] Ohrnberger, D. (1999) The Bamboos of the World. Elsevier, Amsterdam.

[11] Tumuluru, J.S., Sokhansanj, S., Wright, C.T., Boardman, R.D. and Yancey, N. (2011) 
A Review on Biomass Classification and Composition, Co-Firing Issues and Pretreatment Methods. https://inldigitallibrary.inl.gov/sites/sti/sti/5094573.pdf

[12] Stolarski, M.J., Szczukowski, S., Tworkowski, J., Krzyzaniak, M., Gulczynski, P. and Mleczek, M. (2013) Comparison of Quality and Production Cost of Briquettes Made from Agricultural and Forest Origin Biomass. Renewable Energy, 57, 20-26. https://doi.org/10.1016/j.renene.2013.01.005

[13] McKendry, P. (2002) Energy Production from Biomass (Part 1): Overview of Biomass. Bioresource Technology, 83, 37-46. https://doi.org/10.1016/S0960-8524(01)00118-3

[14] EN ISO 17225-1 (2015) Solid Biofuels-Fuel Specifications and Classes-Part 1: General Requirements. ISO, Geneva.

[15] Falemara, B.C., Joshua, V.I., Aina, O.O. and Nuhu, R.D. (2018) Performance Evaluation of the Physical and Combustion Properties of Briquettes Produced from AgroWastes and Wood Residues. Recycling, 3, 37.

https://doi.org/10.3390/recycling3030037

[16] Adegoke, I.A., Baiyewu, R.A., Aina, K.S., Adesope, A.S., Adejoba, A.L. and Abah, G.B. (2010) Combustion Properties of Briquette Produced from Mixed Sawdust of Tropical Wood Species. Climate Change and Forest Resources Management: The Way Forward. Proceedings of the 2nd Biennial National Conference of the Forests and Forest Products Society, Akure, 16-18 April 2010, 368-371.

[17] Emerhi, E.A. (2011) Physical and Combustion Properties of Briquettes Produced from Sawdust of Three Hardwood Species and Different Organic Binders. Advances in Applied Science Research, 2, 236-246.

[18] Ige, A.R., Elinge, C.M., Hassan, L.G., Adegoke, I.A. and Ogala, H. (2018) Effect of Binder on Physicochemical Properties of Fuel Briquettes Produced from Watermelon Peels. AASCIT Journal of Energy, 5, 23-27.

[19] Shukla, S. and Vyas, S. (2015) Study of Biomass Bio Pellets, Factors Affecting Its Performance and Technologies Based on Bio Pellets. IOSR Journal of Environmental Science, Toxicology and Food Technology, 9, 37-44.

[20] Ikelle, I.I. and Anyigor, C. (2014) Comparative Thermal Analysis of the Properties of Coal and Corn Cob Briquettes. IOSR Journal of Applied Chemistry, 7, 93-97. https://doi.org/10.9790/5736-07619397

[21] Ogbuagu, J., Onuegbu, T., Ikelle, I.I., Chimezie, O. and Anyigor, C. (2013) Production and Analysis of the Heating Properties of Coal and Rice Husk Briquettes Using $\mathrm{CaSO}_{4}$ as a Binder. Journal of Physical Science and Innovation, 1, 35-44.

[22] Akowuah, O.J., Kermausuor, F. and Mitchual, J.S. (2012) Physicochemical Characteristics and Market Potential of Sawdust Charcoal Briquette. International Journal of Energy and Environmental Engineering, 3, 18-26.

https://doi.org/10.1186/2251-6832-3-20

[23] Adetogun, A.C., Ogunjobi, K.M. and Are, D.B. (2014) Combustion Properties of Briquettes Produced from Maize Cob of Different Particle Sizes. Journal of Research in Forestry, Wildlife and Environment, 6, 28-38.

[24] Katimbo, A., Nicholas, K., Simon, K., Hussein, B.K. and Peter, T. (2014) Potential of Densification of Mango Waste and Effect of Binders on Produced Briquettes. Agricultural Engineering International: CIGR Journal, 16, 146-155.

[25] Navalta, C.J.L.G., Banaag, K.G.C., Raboy, V.A.O., Go, A.W., Cabatingan, L.K. and Ju, Y.-H. (2020) Solid Fuel from Co-Briquetting of Sugarcane Bagasse and Rice Bran. Renewable Energy, 147, 1941-1958.

https://doi.org/10.1016/j.renene.2019.09.129 
[26] Feng, Z., Zhang, T., Yang, J., Gao, Q., Ni, L. and Liu, Z. (2020) Fuel Characteristics of Briquettes Manufactured by Natural Stacking Bamboo/Chinese Fir Mixtures. ACS Omega, 5, 25281-25288. https://doi.org/10.1021/acsomega.0c03413

[27] Morey, R.V. and Kaliyan, N. (2009) Factors Affecting Strength and Durability of Densified Biomass Products. Biomass Bioenergy, 33, 337-359.

https://doi.org/10.1016/j.biombioe.2008.08.005

[28] Adapa, T.L.P. and Kashaninejad, M. (2011) Biomass Feedstock Pre-Processing-Part 2: Densification. In: Dos Santos Bernardes, M.A., Ed., Biofuel s Engineering Process Technology, InTech, Rijeka, Chapter 19, 439-464. https://doi.org/10.5772/18495

[29] Wang, Z., Qu, L., Qian, J., He, Z. and Yi, S. (2019) Effects of the Ultrasound-Assisted Pretreatments Using Borax and Sodium Hydroxide on the Physicochemical Properties of Chinese Fir. Ultrasonics Sonochemistry, 50, 200-207.

https://doi.org/10.1016/j.ultsonch.2018.09.017

[30] Karunanithy, C., Wang, Y., Muthukumarappan, K. and Pugalendhi, S. (2012) Physiochemical Characterization of Briquettes Made from Different Feedstocks. Biotechnology Research International, 2012, Article ID: 165202.

https://doi.org/10.1155/2012/165202

[31] Obernberger, I. and Thek, G. (2004) Physical Characterisation and Chemical Composition of Densified Biomass Fuels with Regard to Their Combustion Behaviour. Biomass and Bioenergy, 27, 653-669. https://doi.org/10.1016/j.biombioe.2003.07.006

[32] Obi, O.F. and Okongwu, K.C.H. (2016) Characterization of Fuel Briquettes Made from a Blend of Rice Husk and Palm Oil Mill Sludge. Biomass Conversion and Biorefinery, 6, 449-456. https://doi.org/10.1007/s13399-016-0206-X

[33] Wakchaure, G.C. and Mani, I. (2009) Effect of Binders and Pressures on Physical Quality of Some Biomass Briquettes. Journal of Agricultural Engineering, 46, 24-30. https://www.researchgate.net/profile/G C Wakchaure/publication/235944947 Effe ct of Binders and Pressures on Physical Quality of Some Biomass Briquettes/1 inks/02e7e51499eca04887000000.pdf 